\title{
MORPHOMETRY OF UMBILICAL CORD AND ITS RELATION WITH UMBILICAL ARTERIES- A FOETAL STUDY
}

\author{
Sreekumar Rajasekharan'1, Leelabhai Janaki Yovel2 \\ ${ }^{1}$ Assistant Professor, Department of Anatomy, Government Medical College, Thiruvananthapuram. \\ ${ }^{2}$ Professor, Department of Anatomy, SR Medical College and Research Centre, Akhathumuri, Varkala, Thiruvananthapuram.
}

\section{ABSTRACT}

\section{BACKGROUND}

Survival of the foetus depends upon the state of the umbilical cord and the vascularity that it provides. So naturally umbilical cord morphometry and its variations were assumed to be a significant cause for foetal death.

The aim of this study was to study the morphological changes in the umbilical cord and its vasculature seen in dead foetuses.

\section{MATERIALS AND METHODS}

Descriptive methods were used to assess the patterns of intra-group findings in umbilical cord. Total of 110 foetal autopsy cases were considered for this study.

\section{RESULTS}

The length of umbilical cord and its diameter increases with an increase in gestational age. The external diameter of umbilical cord was more in foetuses with normal umbilical cord than the foetuses with single umbilical artery. This may be due to the absence of one of the umbilical arteries.

\section{CONCLUSION}

As umbilical cord anomalies can be diagnosed prenatally, awareness and detection of the conditions in the antenatal period will improve foetal survival and reduce infant mortality.

\section{KEYWORDS}

Morphometry, Umbilical Cord, Umbilical Artery, Foetus.

HOW TO CITE THIS ARTICLE: Rajasekharan S, Yovel LJ. Morphometry of umbilical cord and its relation with umbilical arteries- a foetal study. J. Evolution Med. Dent. Sci. 2017;6(68):4848-4852, DOI: 10.14260/Jemds/2017/1051

\section{BACKGROUND \\ Survival of the foetus during the gestational period depends upon the state of the umbilical cord and the vascularity that it provides. Compromise of the foetal blood flow through the umbilical cord blood vessels can have serious effects on the health of the foetus and the newborn. So naturally umbilical cord anomalies can be a significant cause for foetal death. ${ }^{1}$}

\section{Objectives}

Present study was based on three aspects; first to find out various morphological parameters of umbilical cord in dead foetuses, second to find out the relation between these parameters and number of umbilical arteries and third the umbilical cord anomalies.

\section{MATERIALS AND METHODS}

Materials used for this study consists of foetuses sent to the Department of Pathology of Medical College, Thiruvananthapuram for autopsy. A sample size of 110 was considered for this study. Descriptive study was used to assess the patterns of intra-group findings in umbilical cord.

Financial or Other, Competing Interest: None.

Submission 20-07-2017, Peer Review 11-08-2017,

Acceptance 19-08-2017, Published 24-08-2017.

Corresponding Author:

Dr. Sreekumar Rajasekharan,

Flat.no-615, Block-4,

EMS Nagar, Pattoor, Vanchiyoor P.O.

Thiruvananthapuram-695035.

E-mail: drsreekumarrs@gmail.com

DOI: $10.14260 /$ jemds $/ 2017 / 1051$
The present study is designed to throw some light into the commonly observed cord anomalies observed in foetuses. Along with this its vasculature were noted. Student's ' $t$ ' test and Mann-Whitney U test were used to know the intra-group changes in the foetuses studied. Pearson correlation was used to evaluate the strength of association between variables. Calculation was done using the software Epi Info 2000, version 1.1.2 (CDC, Atlanta, USA).

Autopsy was done only on those foetuses whose gestational age was more than 12 weeks and less than 40 weeks. Foetuses of mothers who were taking teratogenic drugs like sodium valproate, carbamazepine, anti-cancer drugs, warfarin, phenytoin, phenobarbitone and isotretinoin during pregnancy or having maternal infections like TORCH (toxoplasmosis, other [T. pallidum, varicella-zoster virus, Parvovirus B19], Rubella virus, Cytomegalovirus and Herpes simplex virus) during the first trimester, maternal diseases like chronic hypertension, diabetes mellitus and chronic nephritis were excluded from the study.

Informed consent from the mother for recruiting her dead foetus was obtained. The benefits and risks associated with the participation of the foetus in the study were explained to her. After getting the willingness of the mother as the informed consent, the data and other materials regarding the foetus required for the study were collected. One copy of the signed consent form was given to the mother and another signed copy was retained. For statistical purposes, foetal deaths were classified into 3 categories according to the gestational age. Early foetal death is defined as death that occurred at less than 20 weeks of gestation, intermediate foetal death at 20 - 27 weeks of gestation and late foetal death at greater than 28 weeks of gestation. 
Study incorporates procedures conducted during and after the foetal autopsy. Length and thickness of the umbilical cord were measured using measuring tape and Vernier calipers. The patterns of insertion like central, marginal, velamentous, etc. of the umbilical cord on the placenta were recorded. Thickness measured using the Vernier calipers, where the average of three recordings were considered each for the maximum and minimum diameters separately. The number of knots on the cord was counted and recorded.

Umbilical cord tissue was collected from each case and was immediately put in formalin for fixation. Care was taken to see that no placental tissue or other foetal tissue is taken during the tissue collection procedures. The tissue pieces of umbilical cord, which are fixed in $10 \%$ formalin were taken to the Department of Anatomy for doing the histopathological examination. ${ }^{2}$ Wax blocks prepared from the tissues were sectioned at 0.5 micron. Sections were carefully transferred to the surface of water bath using paint brush. Then the sections were collected on a clean glass slide. Haematoxylin and Eosin staining method is used to study the tissue. Slides thus prepared were examined under light microscopy and the number of vessels were noted. All the findings were recorded in a master chart and assessed under the following headings.

\section{Morphologic Parameters}

The different parameters measured in umbilical cord during foetal autopsy are length of umbilical cord, its external diameter, number of coils and coiling index.

\section{Morphologic Parameters based on Umbilical Artery Status \\ Length of umbilical cord, external diameter (thickness) of umbilical cord, number of coils and coiling index (total number of coils per length of umbilical cord) of the umbilical cord were compared with normal and single umbilical artery cases.}

\section{Umbilical Cord Anomalies}

Knots, placental insertion, amniotic band and umbilical cord constriction were noted.

\section{RESULTS}

The study is based on the data collected from 110 foetal autopsies.

\section{Morphologic Parameters}

Length and external diameter of umbilical cord, number of coils and the coiling index were measured. The details are given in Table 1.

\begin{tabular}{|c|c|c|}
\hline Parameter & $\begin{array}{l}\mathrm{N} \text { (No. of } \\
\text { Cases) }\end{array}$ & Mean \pm SEM \\
\hline Length of umbilical cord (cm) & 110 & $25.91 \pm 1.12$ \\
\hline $\begin{array}{l}\text { External diameter of umbilical } \\
\text { cord }(\mathrm{cm})\end{array}$ & 110 & $0.64 \pm 0.22$ \\
\hline Number of coils & 110 & $15.77 \pm 0.85$ \\
\hline Coiling Index & 110 & $0.60 \pm 0.02$ \\
\hline \multicolumn{3}{|c|}{$\begin{array}{l}\text { Table 1. Distribution of Gross Umbilical } \\
\text { Cord Findings in the Study Group }(N=110)\end{array}$} \\
\hline
\end{tabular}

\section{Length of Umbilical Cord}

The average length of umbilical cord in the study population was $25.91 \mathrm{~cm}$. The length of umbilical cord ranged from $4 \mathrm{~cm}$ to $56 \mathrm{~cm}$ in different foetuses studied. An umbilical cord length of more than $30 \mathrm{~cm}$ was found in only $35.45 \%$ cases $(\mathrm{N}=39$ ), out of which only 22 foetuses had completed 28 weeks of gestation. There was a significant $(p<0.01)$ positive correlation between the gestational age and the length of umbilical cord (Pearson's $r=0.69$ ). This shows that the length of umbilical cord increases with an increase in gestational age. Chart 1 shows the mean length of umbilical cord according to the age of the foetus.

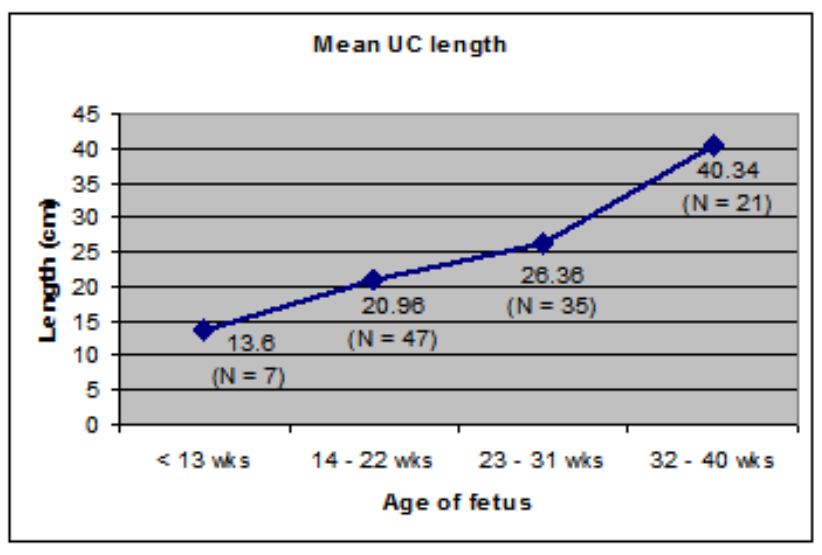

Chart 1. Mean Umbilical Cord Length according to Age of Foetus

\section{External Diameter of Umbilical Cord}

The average external diameter of umbilical cord was $0.64 \mathrm{~cm}$. There was a significant ( $p<0.001$ ) positive correlation between the gestational age and the external diameter of umbilical cord (Pearson's $r=0.41$ ). The diameter of umbilical cord increases with an increase in foetal age.

\section{Number of Coils}

The average number of coils present in an umbilical cord was 15.77 .

2. Relation between Umbilical Cord Parameters and Umbilical Artery Status

Statistical tests were performed to find out whether the gross umbilical cord measurements differed in foetuses with SUA compared to foetuses with normal umbilical artery status. The results are displayed in Table 2 .

\begin{tabular}{|c|c|c|c|}
\hline \multirow[b]{2}{*}{ Parameter } & \multicolumn{2}{|c|}{ Mean \pm SEM } & \multirow[b]{2}{*}{ P Value } \\
\hline & $\begin{array}{c}\text { Single } \\
\text { Umbilical } \\
\text { Artery Cases } \\
(\mathrm{N}=6)\end{array}$ & \begin{tabular}{|c|} 
Normal \\
Umbilical \\
Artery Cases \\
$(\mathrm{N}=\mathbf{1 0 4})$
\end{tabular} & \\
\hline $\begin{array}{l}\text { Length of umbilical } \\
\text { cord }(\mathrm{cm})\end{array}$ & $19.23 \pm 2.80$ & $26.30 \pm 1.16$ & NS \\
\hline $\begin{array}{l}\text { External diameter of } \\
\text { umbilical cord }(\mathrm{cm})\end{array}$ & $0.45 \pm 0.51$ & $0.65 \pm 0.23$ & 0.03 \\
\hline Number of coils & $10.67 \pm 3.37$ & $16.07 \pm 0.87$ & NS \\
\hline Coiling index & $0.49 \pm 0.12$ & $0.60 \pm 0.02$ & NS \\
\hline \multicolumn{4}{|c|}{$\begin{array}{l}\text { Table 2. Distribution of Gross Umbilical Cord } \\
\text { Parameters based on Umbilical Artery Status }\end{array}$} \\
\hline
\end{tabular}


There was a statistically significant difference $(\mathrm{p}<0.05)$ in the external diameter of umbilical cord between SUA cases and the other foetuses with normal umbilical artery status. The external diameter of umbilical cord was more in foetuses with normal umbilical cord than the foetuses with single umbilical artery. This may be due to the absence of one of the umbilical arteries.

\section{Umbilical Cord Anomalies}

Knots of the UC

One true knot and one false knot have noted and shown in Figures 1 and 2. Cross section of the pseudoknot is shown in Figure 3.

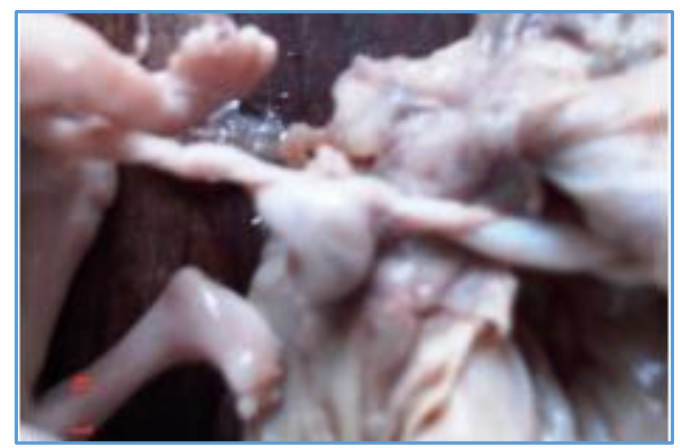

Figure 1. 20 Weeks Foetus with True Knot

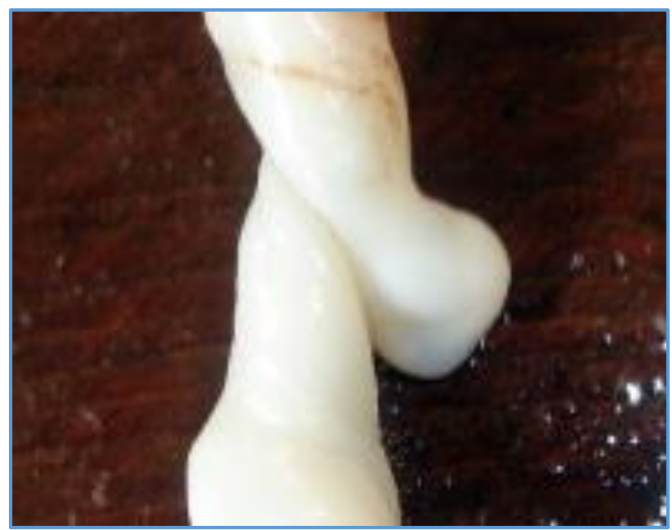

Figure 2. 22 Weeks Foetus with Pseudoknot

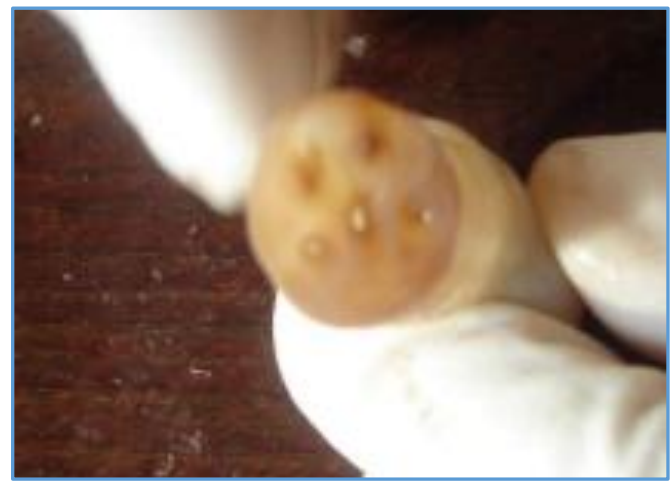

Figure 3. Cross-Section at Pseudoknot

\section{Placental Insertion of UC}

$95.45 \%$ cases $(\mathrm{N}=105)$ were presented with central insertion (Figure 4), 3.64\% cases ( $\mathrm{N}=4$ ) were presented with marginal insertion of the cord (Figure 5) and $0.91 \%$ cases $(\mathrm{N}=1)$ were presented with velamentous insertion of the cord (Figure 6).

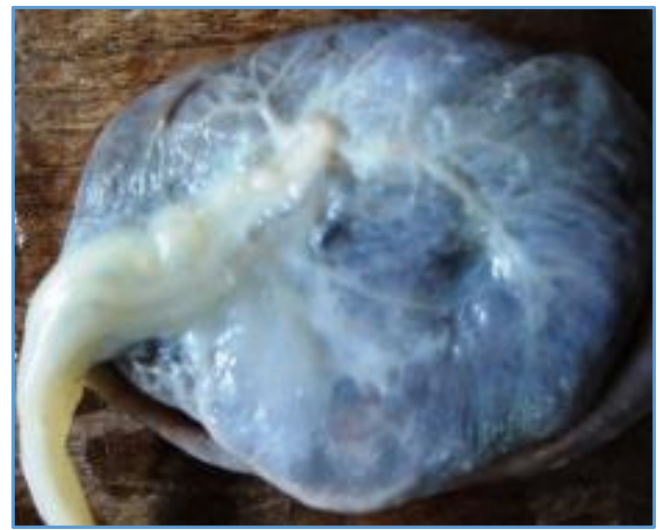

Figure 4. Central Insertion

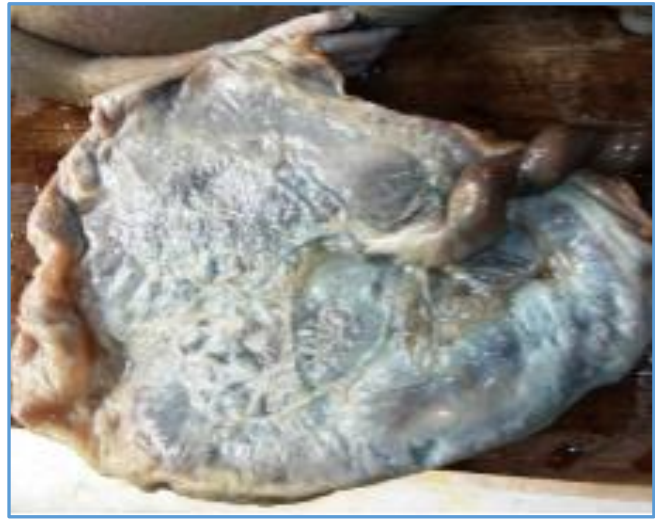

Figure 5. Marginal Insertion

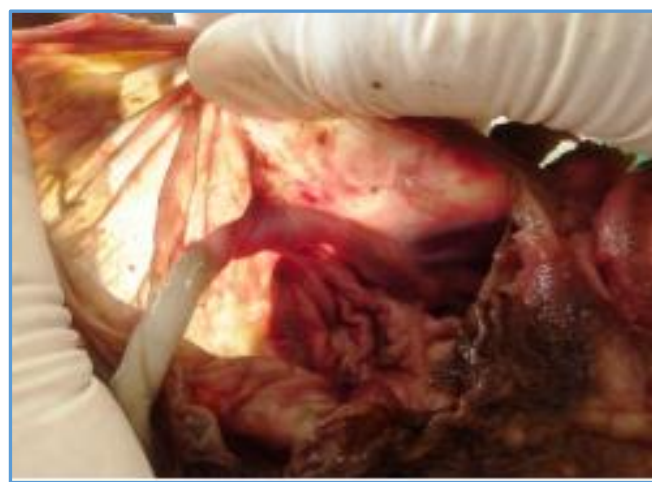

Figure 6. Velamentous Insertion

\section{Amniotic Band}

One case of amniotic band of left thigh was noted (Figure 7).

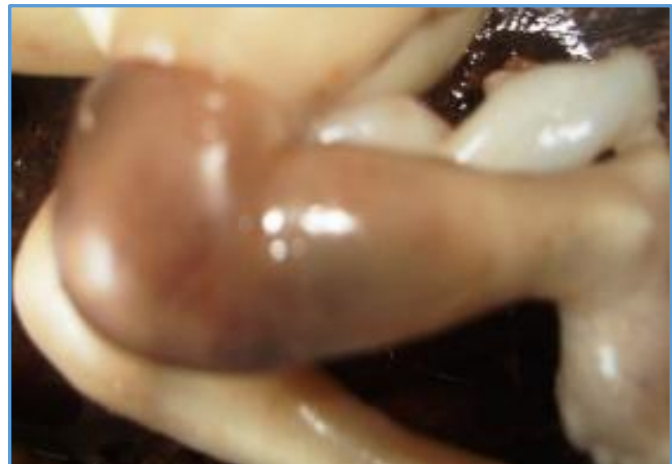

Figure 7. 22 Weeks Foetus with Amniotic Band on Left Thigh 


\section{UC Constriction}

One case of UC constriction was noted near the foetal end of the UC (Figure 8).

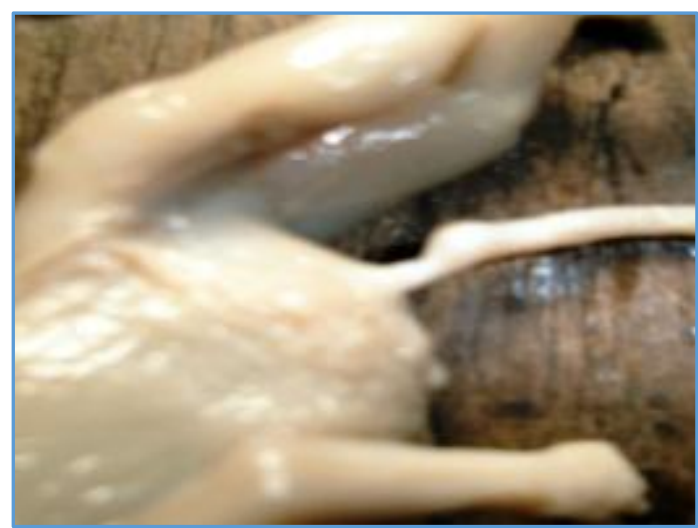

Figure 8. 18 Weeks Foetus with UC Constriction Near Foetal End

\section{DISCUSSION}

The present study was based on gross morphological parameters in umbilical cord with normal and single umbilical artery cases and various umbilical cord anomalies present in them.

\section{Morphometry of Umbilical Cord}

Here length, external diameter (thickness), number of coils and the coiling index of the umbilical cord were measured.

\section{Length of Umbilical Cord}

The average length of the umbilical cord in this study was $25.91 \mathrm{~cm}$. The mean UC length was 13.6 in < 13 weeks, 20.96 in 14 - 22 weeks, 26.36 in 23 - 31 weeks and 40.34 in $32-40$ weeks. The length of the umbilical cord ranged from 4 to $56 \mathrm{~cm}$. An umbilical cord length of more than $30 \mathrm{~cm}$ was found in only $35.45 \%$ cases. There was a significant positive correlation between the gestational age and the length of the umbilical cord. This showed that the length of the umbilical cord increases with gestational age.

Gardiner (1922) established that the minimum cord length which would allow for a normal vertex delivery is 32 $\mathrm{cm} .^{3}$ It has been generally accepted that a cord of or less than this length should be considered as abnormally short. Gardiner opined that a cord length of at least $35.5 \mathrm{~cm}$ is necessary for normal progression of a vaginal delivery without traumatic traction of the cord. According to Miller et al (1981), cord length relates to the stretch placed on the cord by the developing embryo and foetus. ${ }^{4}$ This tension is determined by the availability of intrauterine space and the occurrence of foetal movement. Any situation which limits the early intrauterine space or movement of the foetus may give rise to a short umbilical cord. Thus, the finding of a short umbilical cord may indicate decreased foetal movement in early gestation. According to Purola (1968), the cord length of infants with birth weight more than 2500 grams is $22-130$ cm. ${ }^{5}$ Malpas (1974) described that length of the human umbilical cord in normal infants at term or near term is 30 $129 \mathrm{~cm} .6$ Walker (1960) opined that there is no evidence of growth in cord length after 28 weeks, as the placenta begins to degenerate this time. ${ }^{7}$
2. External Diameter (Thickness) of the Umbilical Cord The average external diameter of the umbilical cord was $0.64 \mathrm{~cm}$. There was significant positive correlation between the gestational age and the external diameter of the umbilical cord. The diameter of the umbilical cord increases with an increase in foetal age.

Predanic and Perni (2005) observed that the mean umbilical cord thickness was $9.48+/-0.97 \quad \mathrm{~mm}^{8}$ Phaloprakarn et al (2004) stated that there was a strong correlation between umbilical cord diameter and gestational age. ${ }^{9}$

\section{Number of Coils of the Umbilical Cord}

The average number of coils of the umbilical cord was 15.77 .

According to Strong et al (1994) normal umbilical cord coiling is approximately one coil per $5 \mathrm{~cm}$ of umbilical cord length, ${ }^{10}$ i.e. approximately 10 coils per total length of umbilical cord. Abnormal umbilical cord coiling, hypo- or hyper-coiling was found to be associated with impaired foetal growth. According to Chaurasia (1979) the true aetiology of umbilical cord coiling is unclear, but it is thought to result from foetal movements as well as unequal vascular growth. ${ }^{11}$ According to Percy Malpas (1966), helical structure of the cord results from the reciprocal action between the intrinsic structures of the vessel walls on the one hand and the pressure, volume and flow rate of foetal blood on the other. ${ }^{12}$ Number of complete twists present in these undistorted cords ranged between 8 and 16. In the present study, number of coils comes in this range.

\section{Coiling Index of the Umbilical Cord}

The average coiling index of the umbilical cord was 0.6. This also does not show any correlation with foetal age.

Strong et al (1994) observed that umbilical cord coiling index was determined by dividing the total number of complete vascular coils by the umbilical cord length in $\mathrm{cms} .{ }^{13}$ The mean coiling index was $0.21+/-0.07$ (SD) coils per cms. The helical smooth muscle fibres of the umbilical arterial vessels were suggested to provide the axis for umbilical cord coiling. The helical twisting of the umbilical cord plays an important role in protection of the fragile vascular system.

\section{Gross Umbilical Cord Parameters based on Umbilical Artery Status}

Length of umbilical cord, external diameter (thickness) of umbilical cord, number of coils and coiling index of the umbilical cord are compared between both normal umbilical artery cases and single umbilical artery cases. There was significant difference in the external diameter of the umbilical cord between single umbilical artery cases and the other foetuses with normal umbilical cord. The external diameter of the cord was more in foetuses with normal umbilical cord $(6.53 \mathrm{~mm})$ than in foetuses with single umbilical artery $(4.45$ $\mathrm{mm})$. Length of umbilical cord, number of coils and coiling index showed no significance. 


\section{Umbilical Cord Anomalies \\ Knots of the Umbilical Cord}

Chasnoff et al stated that incidence of true knots varied from $0.04-1 \%{ }^{14}$ Bronsteen suggested that infants with true knot of the umbilical cord have an increased incidence of congenital anomalies. ${ }^{15}$ One true knot and one false knot has been noted in the present study ( $0.9 \%$ each).

\section{Placental Insertion of the Umbilical Cord}

According to Shanklin, single umbilical artery is associated with higher incidence of marginal and velamentous insertion of the umbilical cord and these anomalies have been found in $5.9 \%$ and $1.2 \%$ of all placentas respectively. ${ }^{16}$ Heifetz found that association of single umbilical artery with velamentous insertion of the umbilical cord slightly increased the risk for other anomalies. ${ }^{17}$ In the present study, velamentous insertion of the cord was $0.91 \%$; $95.45 \%$ cases were presented with central insertion and $3.64 \%$ cases with marginal insertion. In this study, single umbilical artery cases were associated with normal central insertion of umbilical cord.

\section{Amniotic Band}

Sentilhes et al reported a right leg amniotic band, which presented with severe oedema of distal limb and right club foot. ${ }^{18}$ Its pathogenesis includes prior rupture of membranes or early disruption of otherwise normal membranes. ${ }^{19}$ One case of amniotic band in thigh was noted in the present study $(0.9 \%)$.

\section{Umbilical Cord Constriction}

Tavares-Fortuna and Lourdes-Pratas conducted a prospective study and reported an incidence of umbilical cord constriction of 1 in 250 deliveries. ${ }^{20}$ Kiley et al and Konstantinova have reported associated anomalies like tracheo-oesophageal fistula, cleft lip, anencephaly, anophthalmia and exophthalmos. ${ }^{21,22}$ One case of umbilical cord constriction was noted near the foetal end in the present study $(0.9 \%)$.

\section{CONCLUSION}

The average length of umbilical cord in the present study population is $25.91 \mathrm{~cm}$ and the average external diameter of umbilical cord is $0.64 \mathrm{~cm}$. The present study shows that the length of umbilical cord increases with an increase in gestational age. Similarly, it is found that diameter of umbilical cord increases with an increase in foetal age.

There was a significant difference in the external diameter of umbilical cord between SUA cases $(0.45 \mathrm{~cm})$ and the other foetuses with normal umbilical cord $(0.65 \mathrm{~cm})$. The external diameter of umbilical cord was more in foetuses with normal umbilical cord than the foetuses with single umbilical artery. This may be due to the absence of one of the umbilical arteries.

\section{REFERENCES}

[1] Kliman HJ. The umbilical cord. (From the encyclopedia of reproduction). Yale University of School of Medicine 2006:3.

[2] Slaoui M, Fiette L. Histopathology procedures: from tissue sampling to histopathological evaluation. Methods Mol Biol 2011;691:69-82.
[3] Gardiner JP. The umbilical cord: normal length in cord complications; etiology and frequency of coiling. Surg Gynecol Obstet 1922;34:252-6.

[4] Miller ME, Higginbottom M, Smith DW. Short umbilical cord: its origin and relevance. Paediatrics 1981;67(5):618-21.

[5] Purola E. The length and insertion of the umbilical cord. Ann Chir Gynaecol Fenn 1968;57:621-2.

[6] Malpas P. Length of the human umbilical cord at term. Br Med J 1964;1(5384):673-4.

[7] Walker CW, Gillian Pye B. The length of the human umbilical cord. Br Med J 1960;1(5172):546-8.

[8] Predanic M, Perni SC. Absence of a relationship between umbilical cord thickness and coling patterns. J Ultrasound Med 2005;24:1491-6.

[9] Phaloprakarn C, Phupong V, Tannirandorn Y, et al. First trimester umbilical cord and vessel diameters of thai fetuses. J Med Assoc Thai 2004;87(5):481-5.

[10] Strong TH, Jarles DL, Vega JS, et al. The umbilical coiling index. Am J Obstet Gynecol 1994;170(1 Pt 1):29-32.

[11] Chaurasia BD, Agarwal BM. Helical structure of the human umbilical cord. Acta Anat 1979;103(2):226-30.

[12] Malpas P, Symonds EM. Observations on the structure of the human umbilical cord. Surg Gynecol Obstet 1966;123(4):746-50.

[13] Strong TH, Finberg HJ, Mattox JH. Antepartum diagnosis of noncoiled umbilical cords. Am J Obstet Gynecol 1994;170(6):1729-32.

[14] Chasnoff IJ, Fletcher MA. True knot of the umbilical cord. Am J Obstet Gynecol 1977;127(4):425-7.

[15] Dooley SL, Lamb R, Helseth DL. Umbilical cord circumference as a measure of Wharton's jelly: clinical correlates. Abstract 32, sixth annual meeting of the society of perinatal obstetricians. January 30 -February 1, 1986, San Antonio, Texas.

[16] Shanklin DR. The influence of placental lesions on the newborn infant. Pediatr Clin North Am 1970;17(1):2542.

[17] Heifetz SA. Single umbilical artery. A statistical analysis of 237 autopsy cases and review of the literature. Perspect Pediatr Pathol 1984;8(4):345-78.

[18] Sentilhes L, Verspyck E, Eurin D, et al. Favorable outcome of a tight constriction band secondary to amniotic band syndrome. Prenat Diagn 2004;24(3):198-201.

[19] Torpin R. Amniochorionic mesoblastic fibrous strings and amniotic bands: associated constricting fetal malformations or fetal death. Am J Obstet Gynecol 1965;91:65-75.

[20] Tavares-Fortuna JF, Lourdes-Pratas M. Coarctation of the umbilical cord: a cause of intrauterine fetal death. Int J Gynaecol Obstet 1978;15(5):469-73.

[21] Konstantinova B. Malformations of the umbilical cord. Acta Genet Med Gemellol 1977;26(3-4):259-66.

[22] Kiley KC, Perkins CS, Penney LL. Umbilical cord stricture associated with intrauterine fetal demise. A report of two cases. J Reprod Med 1986;31(2):154-6. 